\title{
Investigation of the Effects of Hook Size and Bait Type on the Catch of Whiting, Merlangius merlangus (Linnaeus, 1758) (Gadidae) in Bottom Longline Fisheries of the Black Sea
}

\author{
Bünyamin Arı' ${ }^{1}$, İsmet Balık² (i)
}

Cite this article as: Ari, B., \& Balik, I. (2021). Investigation of the effects of hook size and bait type on the catch of whiting, Merlangius merlangus (Linnaeus, 1758) (Gadidae) in bottom longline fisheries of the Black Sea. Aquatic Sciences and Engineering, 36(2), 72-77.

ORCID IDs of the author:

B.A. 0000-0002-0493-6178;

i.B. $0000-0003-2168-8572$

1Ordu University, Strategy Department, Campus, Ordu, Turkey

${ }^{2}$ Akdeniz University, Kemer Maritime Faculty, Konyaaltı, Antalya, Turkey

Submitted:

10.09.2020

Revision Requested:

20.10.2020

Last Revision Received:

21.10.2020

Accepted:

30.10 .2020

Online Published:

27.01.2021

Correspondence:

İsmet Balık

E-mail:

ibalik@akdeniz.edu.t

CCopyright 2021 The Author(s)

Available online at

https://dergipark.org.tr/ase

\begin{abstract}
This study was carried out along the Ünye coasts of the South-eastern Black Sea (Turkey), in order to investigate the effects of hook size and bait type on the catch of whiting, Merlangius merlangus (Linnaeus, 1758) (Gadidae) in the bottom longline fisheries. For this, a set of bottom longline with a total of a hundred hooks, including 20 from each hook number 2, 4, 6, 8 and 10, was tested in a total of 24 trials twice a month between March 2017 and February 2018. Each hook type was baited with squid, horse mackerel, chicken breast and whiting. During the study, a total of 373 whiting were caught. Most of the whiting catch was obtained with the hook no 2 . With the reduction in hook size, both the amount of catch and the size of the fish caught decreased. Most whiting werecaught by the hooks baited with squid. This was followed by the hooks baited with horse mackerel, chicken breast and whiting, respectively. This result shows that hook size no 2 or larger should be used for catching whiting when using bottom longline in the Ünye coasts of the South-eastern Black Sea. Howev-er, considering the bait types used in this study, it is recommended to use squid as bait. If squid is thought to increase the cost of fishing, alternatively horse mackerel or chicken breast can also be used as bait.
\end{abstract}

Keywords: Bait type, catch, hook size, longline, whiting

\section{INTRODUCTION}

Longline fishing is one of the most traditional and widespread fishing methods throughout the world from small-scale artisanal fishing to modern mechanised longline operations (Björdal \& Løkkeborg, 1996). It is an environmentally friendly fishing method and gives excellent quality and high profitability while requiring only a low fuel consumption (Endal, 1980; Løkkeborg \& Björdal, 1992). Since longline fishing has high selectivity, its use is encouraged for protection in fisheries management. However, it is not possible to expect the same success in a habitat from a longline team used in the fishing of only one species.
Since 2006, fishing with bottom trawls has been forbidden in the South-eastern coasts of the Black Sea (Tarım ve Orman Bakanlığı, 2006). Therefore, the benthic fish species have typically been caught only with gillnets and trammel nets in the south-eastern parts of the Black Sea. However, the use of gillnets in fishing is generally considered to be more efficient when more than one species of fish is caught with the same gillnet. Longline are considered as a type of fishing gear that can easily be arranged according to the target species and size (Løkkeborg \& Björdal, 1992), and, in particular, it can contribute to the renewal of distressed stocks such as whiting and red mullet, Mullus barbatus Linnaeus, 1758 in this part of the Black Sea. In addition, it offers the opportunity to catch fish in 
stony and rocky areas which are not suitable for fishing with other fishing gear but where the fish are densely concentrated.

In longline fisheries, the fish is attracted to the hook by visual motivation, either by natural bait or more commonly in the form of artificial imitations of prey organisms such as lures, jigs and rubber worms. Hook type (size and shape) varies greatly depending on the target species. There is also a great variation in baits used in different longline fisheries, but the major types of bait are either different pelagic fish (e.g. herring, mackerel, sardine, saury) or different species of squid (Björdal, 2009). The bait used in fishing is divided into two groups, namely, natural and artificial. Artificial baits are the those that imitate the creature's favourite prey. Natural bait is the most preferred bait group in longline fisheries and can be a whole fish, live or inanimate fish, cuttlefish and squid, pheasant, mammal, pipe worm, goat, crab, mussel and sea cucumber. In the selection of bait, easy availability, cost, fast deterioration, easy attachment to the hook, easy exit from the hook, and the best way to attract the target fishing features are sought (Illkyaz, Aydın, Soykan \& Kınacıgil, 2012). Different baits have been used in studies on whiting fishing with longline. For example, squid has been used as bait in many previous studies in the bottom longline fisheries and its catching efficiency was found higher than some other bait varieties (Ekanayake, 1999; Özdemir, Ayaz, Gurbet \& Erdem, 2006; illkyaz et al., 2012). Fishing with longlines along the Turkish coasts of the Black Sea is not common. For this reason, most of the fishermen do not have enough information about longline fisheries. The goal of the present study was to investigate the effect of hook size and bait type used in bottom longline on the whiting catch.

\section{MATERIALS AND METHODS}

\section{Study area and experimental fishing trials}

This study was conducted along the Ünye coasts of the South-eastern Black Sea in the area $41^{\circ} 06^{\prime}-41^{\circ} 08^{\prime} \mathrm{N}, 37^{\circ} 22^{\prime}-$ $37^{\circ} 260^{\prime} \mathrm{E}$ (Figure 1).

In the study, a set of bottom longline with 100 hooks was used. Longline have 20 hooks from each of 2, 4, 6, 8 and 10 hook sizes.

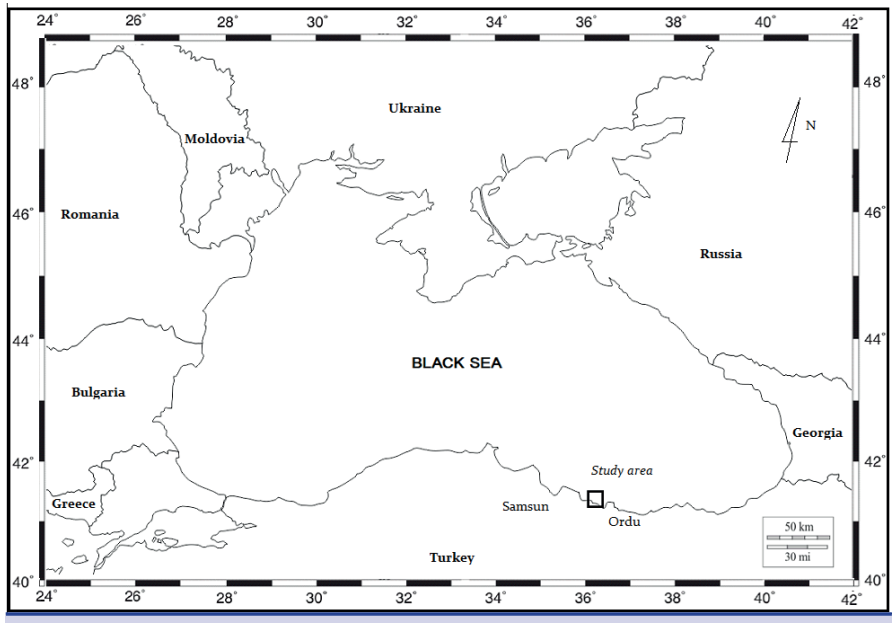

Figure 1. The study area in the Ünye coasts of the Southeastern Black Sea.
Hooks were attached to the main line in order "2,2,2,2; 4,4,4,4; $6,6,6,6 ; 8,8,8,8 ; 10,10,10,10$ ". This procedure was repeated 5 times. The hooks were standard "J" large-shank hooks (Youvella). The structural size measurements of the hooks are shown in Figure 2.

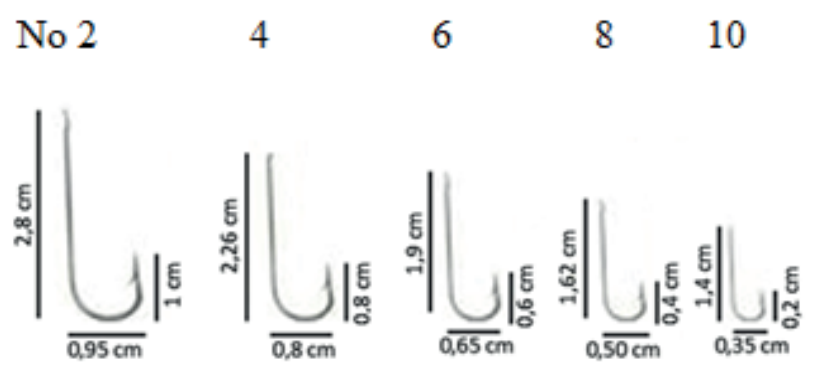

Figure 2. Hooks used in making longline and their structural dimensions.

In addition, technical characteristics of the bottom longline used in the trials are given in Table 1. A plastic basin of $50 \mathrm{~cm}$ diameter was used as the longline basket. Floats are attached to a big cement weight (about $5 \mathrm{~kg}$ ) by means of a rope at the beginning and end of the main line. As seen in Figure 3, during the fishing operation floats and sinkers were attached with a rope at beginning and end of the main line. During the study which was carried out between March 2017 and February 2018, a total of 24 trials were conducted twice a month. The depth of the fishing trials conducted was about $30 \mathrm{~m}$ in the summer when the water temperature increased, while it reached a depth of $80 \mathrm{~m}$ in the winter months. When fishing in shallow areas (30-35 m) during the summer months, the depth went down to $80 \mathrm{~m}$ due to the decrease in water temperature. It is known that this fish species migrates to the waters below the thermocline layer in summer and lives in water temperatures of $7.5-8.5^{\circ} \mathrm{C}$ (Knudsen, Zengin \& Koçak, 2010).

In this study, squid, horse mackerel, whiting and chicken breast were used as bait to investigate the effect of hook size and bait type on catch amount. As mentioned above, many previous studies reported that more fish were caught in the hooks baited with squid. For this reason, squid was also used as bait in the trials. Chicken breast was preferred because it was cheap and eas-

Table 1. Technical characteristics of the bottom longline used in trials

\begin{tabular}{lc}
\hline Gear & Specification \\
\hline Length deployed $(\mathrm{m})$ & $\sim 300 \mathrm{~m}$ \\
Mean soak time (hour) & About one hour \\
Hook type & J-hook \\
Hook size & $2,4,6,8$ and 10 \\
Number of hooks & 20 hooks for each sizes \\
Diameter of main line $(\mathrm{mm})$ & PA multifilament $\varnothing 4.2 \mathrm{~mm}$ \\
Material of branchline (snood) & PA monofilament $\varnothing 30$ \\
Branchline length & $50 \mathrm{~cm}$ \\
Float line & PP $\varnothing 3 \mathrm{~mm}$
\end{tabular}




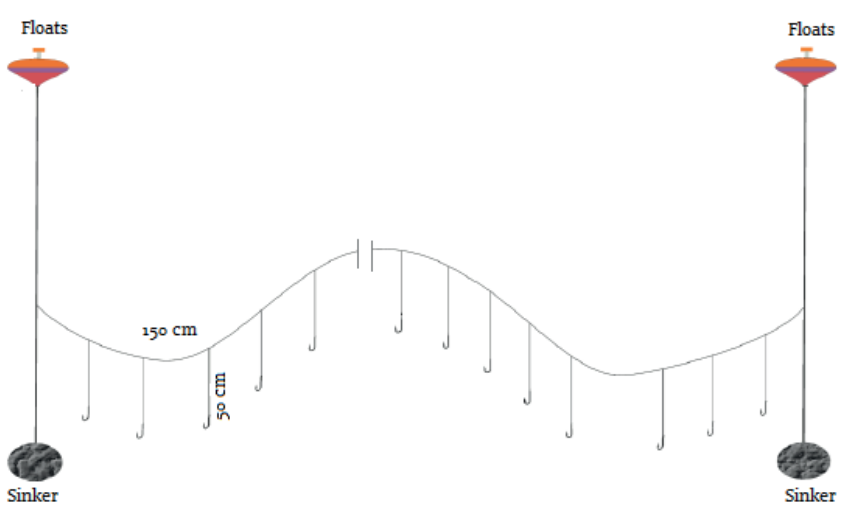

Figure 3. Diagram of longline used in this study.

ily available. In the study, the bait types were cut into cubes wherever possible and in equal sizes proportional to the hook size. In each trial, a total of 20 hooks from each size group were baited with squid, horse mackerel, chicken breast and whiting. A wooden fishing boat of 7.30 m length with $32 \mathrm{HP}$ motor was rented for the fishing trials. Longline remained about one hour at sea and then it was hauled from the sea. After the fish were separated from the hooks, they were classified according to the size of the hooks and the bait types. The total length and weight of the whiting samples were measured to the nearest $1 \mathrm{~mm}$ and weighed to the nearest $0.01 \mathrm{~g}$.

\section{Data analysis}

CPUE $_{n}$ (Catch Per Unit Effort by number of fish) and CPUE $_{b}$ (Catch Per Unit Effort by biomass of fish) were calculated for each hook size and bait type. In the calculation of $\mathrm{CPUE}_{n}$ and $\mathrm{CPUE}_{b}$ equations by Godøy, Furevik \& Løkkeborg (2003) were used:

Catch Per Unit Effort for No. of fish, $\mathrm{CPUE}_{\mathrm{n}}=\frac{\mathrm{N}}{\sum \mathrm{h} * \sum \mathrm{t}}$

Catch Per Unit Effort for biomass, CPUE $_{\mathrm{b}}=\frac{\mathrm{w}}{\sum \mathrm{h} * \sum \mathrm{t}}$

N: No. of fish

W: biomass of fish

h: number of hooks per setting

t: number of setting

\section{Statistical analysis}

First, a normality test (Shapiro-Wilk test) and a homogeneity test (Levene test) were applied to the data. The differences in catch rate and in size among hook sizes and bait types were assessed for each hook size and bait type using one-way analysis of variance (ANOVA, $\alpha=0.05$ ) or Kruskal-Wallis test $(\alpha=0.05)$ for parametric or non-parametric data, respectively. When statistical differences in catch and in fish size were observed, LSD test in para- metric data and Mann-Whitney U-test in non-parametric data were applied for pairwise compare of mean significant differences. Statistical analysis was conducted using SPSS package program.

\section{RESULTS AND DUSCUSSION}

\section{Effect of hook size on catch}

During the study, 373 whiting with a total mass of $8439 \mathrm{~g}$ were caught. Most whiting were obtained with hook no 2 (Table 2). The CPUE $_{b}$ of the whiting caught with hook no 2 was higher by 1.16 , $1.44,1.35$ and 1.46 times than the those caught with hooks no 4, 6,8 and 10 , respectively. $1.24,1.17$ and 1.26 times more whiting were caught with hook no 4 than with hooks no 6, 8 and 10, respectively. On the other hand, hooks no 6, 8 and 10 had similar $\mathrm{CPUE}_{b}$ values of whiting. Catch rates were significantly affected by hook size for whiting fishing (Kruskal-Wallis test; $P<0.05)$. The amount ofwhiting caught with hook no 2 was significantly higher than that caught with hooks no $6(Z=-2.269 ; P=0.023), 8(Z=-$ 2.070; $P=0.038)$ and $10(Z=-3.707 ; P=0.000)$. Similarly, the catch amounts of whiting caught with hooks no 4 and 6 were statistically different (Mann-Whitney $U$ test; $Z=-2.634 ; P=0.008$ ).

Hook size significantly influences the catch amount of a species as well as its size (Patterson, Porch, Tarnecki \& Strelcheck, 2012). Therefore, increasing the hook size can affect catch efficiency and reduce the chances of catching small fish (Alós, Cerdá, Deudero \& Grau, 2008; Campbell, Pollack, Driggers \& Hoffmayer, 2014). Our results indicated that most whiting were caught by hook no 2, while it decreased gradually with decreasing hook size (from 2 to 10). Özdemir et al. (2006) reported that hook size in the bottom longline fisheries in the Gulf of Izmir affects catch amount. On the other hand, Ekanayake (1999) found that in the waters of Sri Lanka the catches were similar for hooks no 7 and 12. It is understood that the effect of hook size on catch amount and fish size may vary from species to species and even from habitat to habitat for the same species.

The weights of the whiting samples varied between $19.3 \mathrm{~g}$ and $26.8 \mathrm{~g}$ and their length ranged from $13.6 \mathrm{~cm}$ to $15.4 \mathrm{~cm}$. Length and weight distributions of whiting samples are shown in Figure 4 and 5. These figures showed that the weight and length of the whiting samples increased with increasing hook size (hook size from no 10 to 2). This paper concludes that the size of the fish caught increases with an increase in hook size. In many studies, it has been concluded that hook size is directly related to the

Table 2. Number (N), Biomass (g), CPUE (No. of fish hook $\left.^{-1} h^{-1}\right)$ and CPUE $\left(\right.$ hook $\left.^{-1} h^{-1}\right)$ of the whiting by hook size

\begin{tabular}{lllll}
\hline Hook no & $\begin{array}{l}\text { No. of Fish } \\
(\mathbf{N})\end{array}$ & $\begin{array}{l}\text { Biomass } \\
(\mathbf{g})\end{array}$ & $\begin{array}{l}\text { CPUE }_{\mathrm{n}} \\
(\mathbf{N})\end{array}$ & $\begin{array}{l}\text { CPUE }_{\mathrm{n}} \\
\text { (weight) }\end{array}$ \\
\hline 2 & 79 & 2119 & 0.165 & 4.415 \\
4 & 80 & 1830 & 0.167 & 3.813 \\
6 & 68 & 1470 & 0.142 & 3.063 \\
8 & 71 & 1570 & 0.148 & 3.271 \\
10 & 75 & 1450 & 0.156 & 3.021
\end{tabular}


length of the fish caught. For example, McCracken (1963) and Saetersdal (1963) conclude that the lengths of Gadus morhua and Merlanogrammus aeglefinus in the longline fishery increased with increasing hook size. In the study carried out by Çekiç \& Başusta (2004) in the Mediterranean, it was found that the fishcaught by hooks no. 8 and 10 were larger than those caught by hook no. 14. Erzini, Gonçalves, Bentes \& Lino (1995) also reported similar results.

The results of the pairwise comparisons with the Mann-Whitney $U$ test showed that the difference of average weights were statistically significant between hooks no 2 and $6(Z=-2.269 ; P=0.023)$,

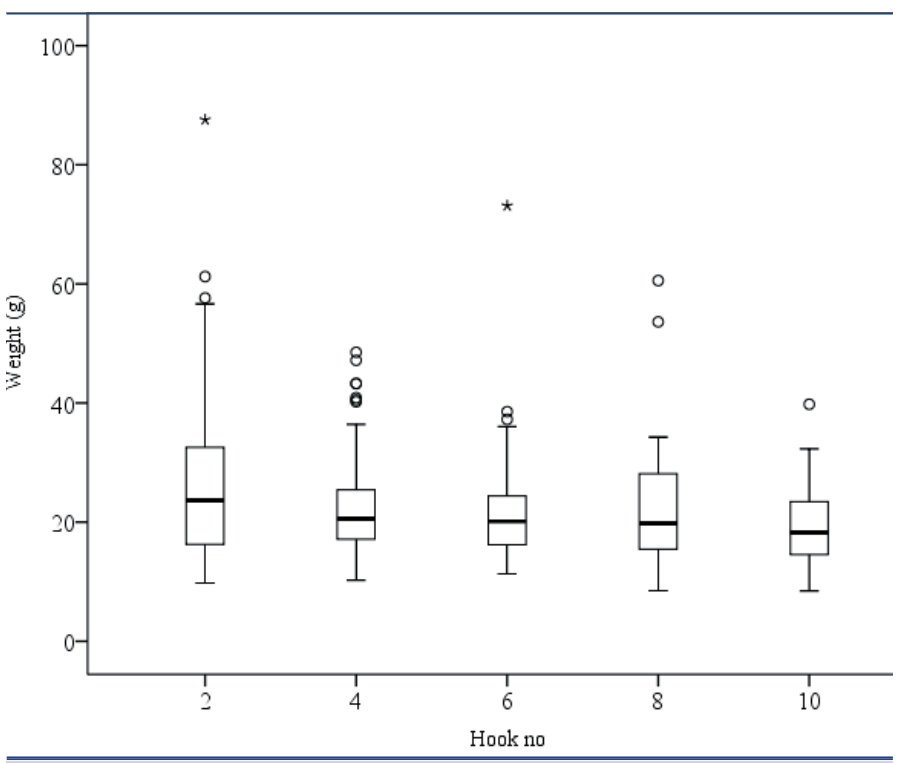

Figure 4. Weight distribution of whiting samples caught by hook size.

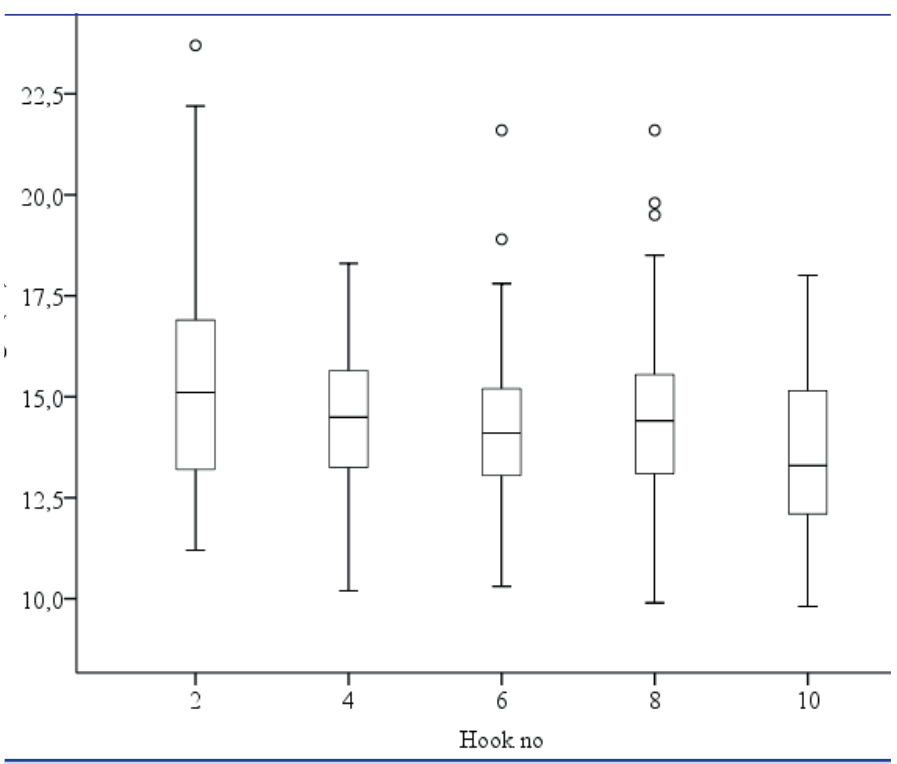

Figure 5. Length distribution of whiting samples caught by hook size.
2 and $8(Z=-2.070 ; P=0.038), 2$ and $10(Z=-3.707 ; P=0.000), 4$ and $10(Z=-2.634 ; P=0.008)$. In terms of average length, differences were found to be significant between hooks no 2 and $6(Z=-$ 2.861; $P=0.004), 2$ and $8(Z=-2.101 ; P=0.036), 2$ and $10(Z=-4.321$; $P=0.000), 4$ and $10(Z=-3.160 ; P=0.002), 8$ and $10(Z=-2.160$; $\mathrm{P}=0.031)$.

\section{Effect of bait type on catch}

Most of the whiting were caught by hooks baited with squid (114 individuals, $2517 \mathrm{~g}$ ). This bait type was followed by horse mackerel in biomass (Table 3 ). In terms of the effect of the bait type on catching yield, squid $(Z=-2.823 ; P=0.005)$, horse mackerel $(Z=-$ 2.624; $P=0.009)$ and chicken breast $(Z=-2.673 ; P=0.008)$ were different from whiting.

Table 3. Number (N), Biomass (g), CPUE (No. of fish hook $\left.^{-1} h^{-1}\right)$ and CPUE $_{b}\left(\right.$ hook $\left.^{-1} h^{-1}\right)$ of the whiting by bait types

\begin{tabular}{|c|c|c|c|c|}
\hline Bait & $\begin{array}{c}\text { Fish } \\
\text { number }\end{array}$ & Biomass (g) & CPUE $_{n}$ & $\mathrm{CPUE}_{\mathrm{b}}$ \\
\hline Squid & 114 & 2.517 & 0.190 & 4.195 \\
\hline $\begin{array}{l}\text { Horse } \\
\text { mackerel }\end{array}$ & 98 & 2.353 & 0.163 & 3.922 \\
\hline $\begin{array}{l}\text { Chicken } \\
\text { breast }\end{array}$ & 100 & 2.259 & 0.167 & 3.765 \\
\hline Whiting & 61 & 1.310 & 0.102 & 2.183 \\
\hline
\end{tabular}

CPUE $_{b}$ of whiting for squid was $1.07,1.11$ and 1.92 times higher than that of the horse mackerel, chicken breast and whiting, respectively. Statistical analyses showed that there was no difference among the average weights $\left(\boldsymbol{X}^{2}=2.501\right.$, $\left.\mathrm{df}=3, \mathrm{P}=0.475\right)$ and the average lengths $\left(\boldsymbol{X}^{2}=3.155, \mathrm{df}=3, \mathrm{P}=0.368\right)$ of the whiting caught with bait variety. In other words, bait types used in this study did not affect the size of the whiting caught for the longline fisheries in the south-eastern Black Sea. The behaviour of the fish that is directed to longline is affected by the bait at all stages of the process of catching the hook, searching for the location of the bait, attacking the food, inserting the bait in the mouth, or inserting it into the hook (Løkkeborg, 1989). The effect of nutrient availability is the first necessary step during feeding. Almost all fish use their sniffing senses to locate a distant bait. On the other hand, baits leave chemical stimulants that will affect living things in the environment. The chemical structure of the bait also affects the feeding preference of the species. In addition, the species' vision, sniffing senses and mouth structure, depending on both hook shape and bait size, has an effect on the amount and composition of catch (Løkkeborg \& Johannesen, 1992).

This is clearly seen in Figures 6 and 7 showing the weight and length distributions of the whiting samples caught by the bait varieties. The average weight of the whiting caught with bait varieties ranged from 21.9 to $24.0 \mathrm{~g}$ and the average length ranged from 14.2 to $14.7 \mathrm{~cm}$.

The main factors affecting longline fishing are migration movements and behaviours of target species or species in longline 


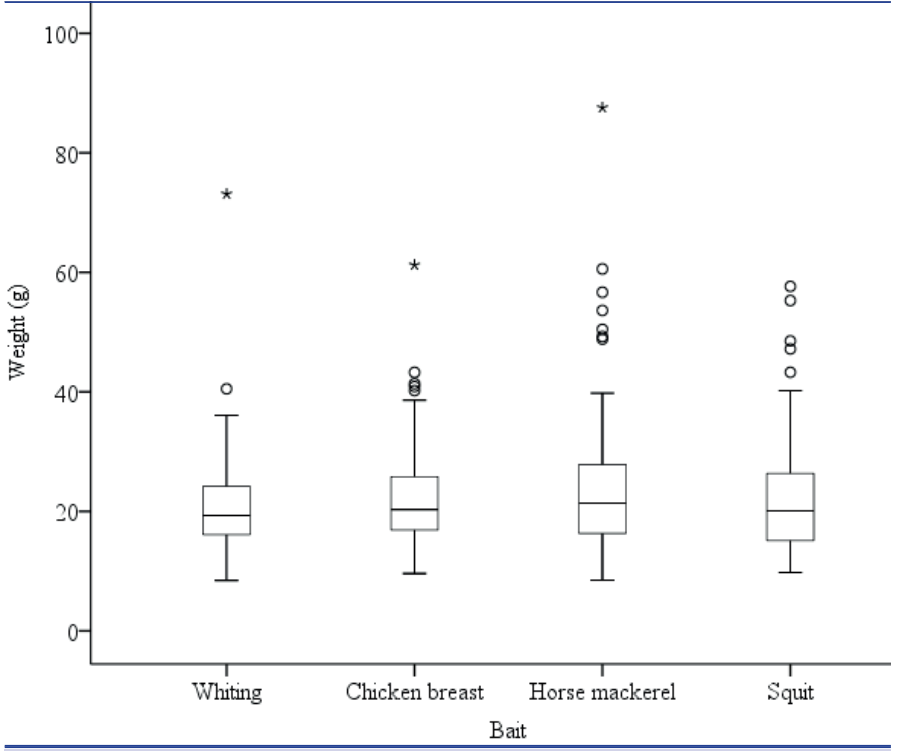

Figure 6. Weight distribution of whiting samples caught by bait type.

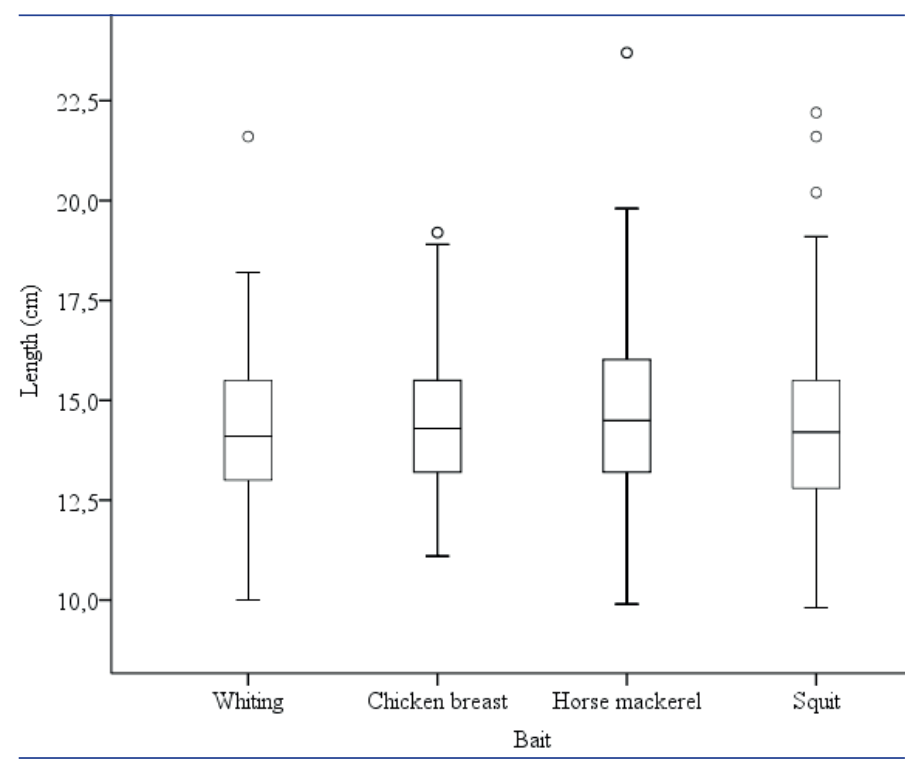

Figure 7. Length distribution of whiting samples caught by bait type.

fishing, their depth, water movements, feed type, the physical properties of the hooks used, catching time and duration, physical properties of the main body and shackle materials (Björdal, 1981). Our study determined that most whiting was caught by hook baited with squid. This bait was followed by chicken breast and horse mackerel, respectively. Hooks baited with whiting yielded the least catch of whiting. It is noteworthy that some longline studies show catching efficiency to be high where squid, or other cephalopod, and horse mackerel are used as bait. For example, in a study conducted on the coast of Sinop, 64\% and $36 \%$ of the total catch in weight was caught by hooks baited with horse mackerel and anchovy, respectively (Özdemir, Erdem \&
Çetin, 2007). In a similar study conducted by Çekiç \& Başusta (2004) in the Gulf of Iskenderun it was reported that 473 of a total of 1059 fish were caught by hooks baited with squid, and 586 of them were caught by hooks baited with sardine. In another longline fisheries study in Izmir Bay, the catch ratio of hooks baited with sardine and squid-fed hooks was found to be 1: 3.5 (Özdemir et al., 2006). In a study conducted in Sri Lankan waters, it was reported that $36.5 \%$ of the total catch was caught by hoosk baited with squid, $27.7 \%$ by hooks baited with herring and $35.9 \%$ by hooks baited with sand snakes (Ekanayake, 1999). According to $\mathrm{He}(1996)$ the squid as bait remains longer on the hook than the fish as bait. This affects catching efficiency. Both the results of our study and the results of the above mentioned studies show that whiting generally prefer squid and horse mackerel as bait in longline fisheries. Almost all the whiting caught with hooks used in the study were determined to be larger than the minimum landing size (Tarım ve Köyişleri Bakanlığı, 2016). This shows that when compared to bottom trawl fishing, longline fishing does not harm the whiting population.

\section{CONCLUSION}

The results of our research show that while the number of whiting caught did not differ significantly with the increase in hook size, the size of whiting caught increased with hook size. Therefore, the hook number to be used in longlines for fishing of whiting in the south-eastern Black Sea should be size 2 or larger. In this way, a greater catch of whiting will be obtained while at the same time preventing the fishing of small whiting. When the bait types used in our study are taken into consideration, squid should be used as a bait for the fishing of whiting with longline. Alternatively, Mediterranean horse mackerel meat and chicken breast can also be a choice of bait in bottom longline fishing.

Conflict of interest: The authors declare no financial, commercial and legal conflict of interest.

Ethics committee approval: The authors declare that this studydoes not need ethics committee approval.

Financial disclosure: This study was supported by TF-1641 project by Ordu University Scientific Research Projects Coordination Unit and produced from the master thesis prepared by the first author under the supervision of the second author.

\section{REFERENCES}

Alós, J., Cerdá, M., Deudero, S. \& Grau, A.M. (2008). Influence of hook size and type on short-term mortality, hooking location and size selectivity in a Spanish recreational fishery. Journal of Applied Ichthyology, 24, 658-663. [CrossRef]

Björdal, A. \& Lokkebor, S. (1996). Longlining. Oxford: Fishing News Books, $56 \mathrm{p}$

Björdal, A. (1981). Engineering and fish reaction aspects of longlining - a review. ICES CM.1981/B35, $22 \mathrm{p}$.

Björdal, A. (2009). Regulation of Fishing Gears and Methods. In K.L. Cochrane \& S.M. Garcia (Eds.), A Fishery Manager's Guidebook (pp. 167-195). Roma, Italy: Second Edition, Published by The Food and Agriculture Organization of the United Nations and Wiley-Blackwell.

Campbell, M.D., Pollack, A.G., Driggers, W.B. \& Hoffmayer, E.R. (2014). Estimation of hook selectivity of Red Snapper and Vermilion Snapper 
from fishery-independent surveys of natural reefs in the northern Gulf of Mexico. Marine and Coastal Fisheries: Dynamics, Management, and Ecosystem Science [online serial] 6, 260-273. [CrossRef]

Çekiç, M. \& Başusta, N. (2004). İskenderun Körfezi'nde Kullanılan Paraketa Takımlarında Yem Çeşidi ve İğne Büyüklüğünün Tür Seçimine Etkisi. Ege Üniversitesi Su Ürünleri Dergisi, 21(1-2), 73-77.

Ekanayake, E.M.A.B. (1999). The effect of hook size and bait type on the fishing selectivity of longline gear (Report No. UNU - Fisheries Training Programme, Final Projects). National Institute of Fisheries Training, Sri Lanka, 23 p.

Endal, A. (1980). Fuel saving potential in Norwegian Fisheries (C.M. 1980/B:14). Trondheim, Norway, $16 \mathrm{p}$.

Erzini, K., Gonçalves, J. M. S., Bentes, L. \& Lino, P.S. (1995). Small Hook Longline Selectivity Study (Report No. BIOECO/93/04). Portugal, 3-17 p.

Godøy, H., Furevik, D. \& Løkkeborg, S. (2003). Reduced by catch of red king crab (Paralithodes camtschaticus) in the gillnet fishery for cod (Gadus morhua) in northern Norway. Fisheries Research, 62, 337-384. [CrossRef]

He, P. (1996). Bait Loss Bottom-Set Longlines As Determined by Underwater Observations and Comparative Fishing Trials. Fisheries Research, 27 (1-3), 29-36. [CrossRef]

Illkyaz, A., Aydın, C., Soykan, O. \& Kınacıgil, T. (2012). Dip Paragatında Yem Etkinliği ve Iğne Seçiciliği. Ege Üniversitesi Bilimsel Araştırma Proje Kesin Raporu, PROJE NO. 2007/SÜF/012, İzmir, 46 p.

Knudsen, S., Zengin, M. \& Koçak, M.H. (2010). Identifying drivers for fishing pressure. A multidisciplinary study of trawl and sea snail fisheries in Samsun, Black Sea coast of Turkey. Ocean and Coastal Management, 53, 252-269. [CrossRef]
Løkkeborg, S. \& Björdal, A. (1992). Species and Size Selectivity in Longline Fishing. Fisheries Research, 13, 311-322. [CrossRef]

Løkkeborg, S. \& Johannessen, T. (1992). The Importance of Chemical Stimuli in Bait Fishing-Fishing Trials with Pre-soaked Bait. Fisheries Research, 14, 21-29. [CrossRef]

Løkkeborg, S. (1989). Longline bait: Fish behaviour and the influence of attractant release rate and bait appearance (PhD Thesis). Department of Biology, University of Bergen, Bergen, Norway.

McCracken, F. D. (1963). Selection by codend meshes and hooks on cod, haddock, flatfish and redfish. In N. S. Dartmouth (Ed.), The selectivity of fishing gear (647-665). Canada: International Commission for the Northwest Atlantic Fisheries (ICNAF) Special Publication 5.

Özdemir, S., Ayaz, A., Gurbet, R. \& Erdem, Y. (2006). Farklı büyüklükte kanca ve farklı tipteki yem ile sabah tanı ve Gündüz zamanlarında kullanılan dip paraketasının av verimi. Anadolu Üniversitesi Bilim ve Teknoloji Dergisi, 7(2), 405-411.

Özdemir, S., Erdem, Y. \& Çetin, S. (2007). Dip paraketasında kullanılan iki farklı yemin balık davranışları ve av verimi yönünden karşılaştırılması. Celal Bayar Üniversitesi Fen Bilimleri Dergisi, 3, 177-187.

Patterson, W.F., Porch, C.E., Tarnecki, J.H. \& Strelcheck, A.J. (2012). Effect of circle hook size on reef fish catch rates, species composition, and selectivity in the northern Gulf of Mexico recreational fishery. Bulletin of Marine Science, 88, 647-665. [CrossRef]

Saetersdal, G. (1963). Selectivity of longlines. ICNAF Spec. Publ. 5, 189192. [CrossRef]

Tarım ve Orman Bakanlığı (2006). Denizlerde ve İçsularda Ticari Amaçı ıu Ürünleri Avcılığını Düzenleyen 2006-2008 Av Dönemine Ait 37/1 Numaralı Sirküler. 24.08.2006 Tarih ve 26269 Sayılı Resmi Gazete. 